\title{
A reescrita da trajetória de Capitu
}

\section{Lucia Osana Zolin}

Professora Doutora da Universidade Estadual de Maringá.

Resumo: Esse artigo investiga a construção das personagens femininas Bia, Capitu e Ana Lúcia em $A$ audácia dessa mulher, de Ana Maria Machado. A partir da intertextualidade com Dom Casmurro, premeditada pela autora, buscamos compreender como as duas obras, juntas, formam um microcosmo das transformaçōes relacionadas ao gênero na sociedade brasileira dos séculos XIX e XX. É o que se vê na análise da forma como a mulher é representada em ambos os livros, no contraste entre a Capitu de Machado de Assis, silenciada, e a Capitu revisitada por Ana Maria Machado, personagem com poder de narrar a própria história, ou seja, de construir (ou reconstruir) a própria identidade.

Palavras-chave: critica feminista; gênero; reescrita

\section{Leila Wanderléla Bonetti Farias}

Mestre pela Universidade Estadual de Maringá.

Abstract: This article investigates the construction of the female characters Bia, Capitu and Ana Lúcia, in A audácia dessa mulher, by Ana Maria Machado. Observing the intertextuality with Dom Casmurro, premeditated by Ana Maria Machado, we try to understand how the two works taken together form a microcosm of gender-related transformations in the Brazilian society of the nineteenth and twentieth centuries. This is what we see by analyzing the way woman is represented in both books, in the contrast between the silenced Capitu by Machado de Assis, and Ana Maria Machado's revised Capitu, a character who has the power to narrate her own story, that is, to build (or rebuild) her own identity.

Keywords: feminist criticism; gender; re-writing 
$$
\text { . }
$$ 
O Pós-estruturalismo encara a literatura como um discurso entre tantos outros discursos. Foucault (1979) definiu o termo discurso como o sistema de afirmações pelas quais se conhece a realidade, um apanhado de significados e práticas que rege a existência e as interações sociais e organiza as relações entre sujeito e objeto. Do ângulo pós-estruturalista, o que seria a "condição especial" da literatura resume-se na diferença de sua linguagem. Nesse sentido, tal posicionamento afirma que "não há realmente nada fora da linguagem, fora da textualidade, fora da representação - tudo se torna, num certo sentido, literatura" (AHMAD, 2002, p. 67). Isso porque a linguagem, modo pelo qual apreendemos e organizamos a realidade, é simbólica; ou seja, é um jogo de diferenças e representações, e não de relações inequívocas entre signos e seus referenciais, que seriam seus correspondentes no mundo "real".

Tal posicionamento pós-estruturalista empenha-se em perpetrar, investigar e desvendar, no intercâmbio entre literatura e história, as relações humanas e suas constituintes como representadas no mundo ficcional, revelando ideologias e discursos com o intuito de intervir na maneira de abordar e apreender a literatura e, por conseguinte, contribuir para modificar a sociedade presente através da renovação da mentalidade da mesma.

Sob a égide pós-estrutural, as construções teóricas referentes aos Estudos Culturais - os quais abrangem o Pós-colonialismo e o Feminismo apontam para o acontecimento no qual a linguagem e a literatura representam a realidade no próprio ato de recriá-la, seja autorizando-a, seja subvertendo-a. Neste enfoque, literatura e instituição literária não pairam acima da realidade; mas, ao mesmo tempo, constituem-na e constituem-se dela. Representam o real por dentro, fazendo parte dele mesmo, afetandoo e sendo por ele afetadas.

Conforme Loomba (1998) esclarece, a abrangência do campo de representações simbólicas da literatura lhe 
confere a capacidade frequente de absorver e marcar aspectos de outras culturas e, ao longo desse processo, criar novos gêneros, ideias e identidades. Por outro lado, a literatura é também um meio importante de apropriação, inversão ou desafio a meios de representação dominantes. Daí pode-se compreender a importância fundamental do binômio linguagem/literatura na construção das práticas sociais e culturais.

Esse poder que reveste a linguagem pode se manifestar de diversas formas. Uma delas se constitui na prática da reescrita. No âmbito dos estudos póscolonialistas, a reescrita consiste em uma estratégia bastante recorrente com a qual se pretende edificar uma visão crítica acerca de determinado corpus literário e da ideologia que subjaz a ele. Mais do que operar a intertextualidade, essa espécie de releitura e revalorização do passado funciona como uma prática de resistência à homogeneização presente no discurso dominante. O instrumento que utiliza é a recriação de textos canônicos preexistentes. Estes são re-inventados, e resultam em novas produções que abrigam outras versões da mesma história. Sob esse novo prisma, possibilitado por um olhar diverso daquele que orientou o texto originário, as recriações advindas da reescrita revelam aspectos encobertos da engenharia discursiva presentificada em textos modelares.

Em O Pós-colonialismo e a literatura (2000), Bonnici define a reescrita como uma estratégia em que "o autor se apropria de um texto da metrópole, geralmente canônico, problematiza a fábula, os personagens ou sua estrutura e cria um novo texto que funciona como resposta pós-colonial à ideologia contida no primeiro texto" (p. 40). Como exemplo, o crítico cita $A$ tempestade, de Shakespeare, como sendo, provavelmente, o texto mais reescrito da literatura canônica inglesa. Nele, percebe-se o papel incisivo que assume o sujeito, isto é, aquele que age, que impõe seu domínio. Ele se constrói no ato de subjugar o outro, requerendo para si qualidades que institui 
como desejáveis, e apontando naquele a "falta" de tais características. Portanto, o sujeito precisa do outro para se firmar como tal, pois este outro inferiorizado é construído como seu "oposto", diante do qual ele se sobressai, ao utilizar-se das categorias comparativas que criou. Nas reescritas construídas sob esse viés, a problemática metrópole-colônia é retomada de modo a salientar os atributos que fazem do texto original uma espécie de roteiro, no qual se pode encontrar os principais argumentos ideológicos do projeto colonial inglês, dentre os quais destaca-se a construção da figura do nativo como "o outro", o diferente, portanto, o inferior e, por isso mesmo, passível de dominação.

É necessário acrescentar que essa outremização, ou seja, a transformação do indivíduo em objeto da ação do sujeito se estrutura em elementos binários opositivos, aos quais se opõe a desconstrução proposta por Derrida (2002). O referido filósofo apresenta categorias que foram estabelecidas em posições hierárquicas, tais como eu/ outro, sujeito/objeto, homem/mulher. O primeiro termo é sempre privilegiado, constituindo-se como centro, em detrimento do segundo, posto como margem, periferia. Nessa hierarquia, os termos bom, verdade, masculinidade, branco formam o centro, enquanto mau, falsidade, feminilidade, preto fazem parte da periferia.

Dessa forma, o centralismo ocidental tem promovido uma eleição que, através de um "discurso cultural que relega e confina o não-europeu a um estatuto racial, cultural e ontológico secundário" (SAID, 1995, p. 96), situa os indivíduos em sujeitos ou objetos, partindo da diferenciação entre o eu (privilegiado) e o outro (marginalizado). Esse foi o principal argumento legitimador da usurpação do Novo Mundo pelo europeu.

No entanto, tal processo não ocorre somente entre colonizadores e colonizados, tampouco se restringe ao terreno da exploração física do território do outro colonizado pelo Outro dominador. A denigrição do outro por meio de estereótipos como os de selvageria, preguiça 
e hiper-sexualidade ainda subsiste, e é prática comum também em diversos tipos de relações, com suas implicações específicas, seja entre patrão e empregado, branco e negro, homem e mulher, adulto e criança, etc.

Semelhantemente ao texto de Shakespeare, que deu margem para o desvendamento da ideologia de exploração que o sustentava, Robinson Crusoé (1719), de Daniel Defoe, inspirou diversas reescritas, dentre as quais destaca-se Foe (1987), do sul-africano Coetzee. Se no texto original o leitor se depara com a clássica imponência da figura do europeu (na personagem do náufrago Crusoé) diante da fragilidade do não-europeu e/ou do nativo (na figura do índio Friday), impondo-lhe sua cultura, num relacionamento claramente hierárquico, que pressupõe a dicotomia colonizador-colonizado, portanto, dominadordominado, na resposta de Foe a este texto, o colonizador/ dominador "é colocado numa luz com efeitos opostos" (BONNICI, 2000, p. 89). Isso implica, por exemplo, pôr em cena uma mulher como narradora - figura inexistente em Robinson Crusoé - empenhada na recuperação da voz do mudo Friday, sedenta por resgatar-lhe a identidade. Intento este que é conseguido na última parte do romance, ao que tudo indica, narrada pelo próprio Friday que, por meio da escrita, consegue expressar sua descoberta da "imagem de um mundo perdido submetido ao colonizador. Essa imagem o faz descobrir sua subjetividade, sua história, sua autonomia" (BONNICI, 2000, p. 92).

Dessa forma, a "missão civilizadora" da qual o homem branco europeu se incumbiu é revelada em seus propósitos concretos. A reescrita expõe as intenções de espoliação subjacentes a esse discurso. Essa prática de desconstrução e reconstrução é essencialmente contraargumentativa, e demonstra as formas pelas quais o texto subjacente contradiz os próprios pressupostos de civilização, democracia, igualdade, cooperação, justiça, estética, sensibilidade, que se propõe a estampar. O objetivo da reescrita é trazer à tona, discutir e provocar os indivíduos em relação às ideologias opressoras, as quais 
mascaram seu funcionamento como se este correspondesse à lógica natural das coisas. No processo de revelar e salientar aspectos não contemplados anteriormente, movimentos, relações que poderiam permanecer subterrâneas, torna-se claro que a lógica imposta e posteriormente desnudada representa apenas um ponto de vista - o das elites privilegiadas que constituem o centro, e estendem seus braços às mais diversas ramificações das relações entre os seres.

Menciono, ainda, um terceiro e último exemplo de reescrita realizada à luz do Pós-colonialismo. Trata-se de Wide Sargasso Sea (1966), da escritora caribenha Jean Rhys, romance que se apropria da história contada por Charlotte Brontë no clássico Jane Eyre(1847) para, então, recriá-la, salientando questões de gênero, racismo, escravidão e colonialismo, as quais não são problematizadas no texto original. Assim, enquanto no romance de Brontë, a esposa louca de Mr. Rochester morre queimada no sótão, sem maiores delongas, abrindo, portanto, caminho para que o marido se case com a serva Jane Eyre, na reescrita de Rhys, sua loucura é historicizada, sua opressão é posta em discussão. E a discussão surge para decretar o fim do silêncio.

No jogo de dominação construído e reforçado na linguagem, do qual a esposa de Mr. Rochester foi objeto, o cerceamento do acesso aos meios linguísticos para exercer a fala e a argumentação junto ao dominador demonstra a usurpação da possibilidade de resistência no terreno da linguagem. Esta, por sua vez, leva à incapacidade de a mulher reaver o comando do próprio destino, condicionado à capacidade de assumir o controle da representação de si mesma como sujeito. Analogamente à recriação da experiência individual praticada pela reescrita do texto, a ideologia patriarcal que subjugou as mulheres difundiu-se e perpetuou-se, em grande parte, através do poder encerrado na linguagem, e manifestado de diversas formas nas mais diferentes línguas. 
Conforme a teoria do discurso de Foucault (1979), a língua é um sistema de conhecimento social com regras bem delimitadas de inclusão e exclusão. Nesse sistema, um subjuga o outro num discurso opositivo que estabelece relações baseadas numa hierarquia, através da qual somos engendrados no poder e dele passamos a fazer parte, mesmo inconscientemente. Sendo assim, solapar as bases da dominação exige um processo que se aproprie das mesmas ferramentas - no caso, a língua - e desconstrua o discurso dominante.

Tendo sido imbuída do direito de falar, Antoinette, ao contrário da silenciada Bertha, narra sua "história de espoliação praticada pelo marido inglês na fazenda dela no Caribe". O controle do poder de narrar revela a atitude de sujeito, ou seja, de indivíduo agente, assumida por Antoinette. Do mesmo modo, o incêndio da mansão, do qual ela é a autora, ao invés de morrer nele como no texto de Brontë, "mostra a resposta da mulher 'colonizada' diante da arrogância e domínio do europeu" (BONNICI, 2000, p. 24).

Mesmo um rápido passeio, como esse, por entre a teia narrativa desse curioso romance caribenho deixa clara a existência de estreitas ligações entre a opressão da mulher e a opressão do colonizado. A personagem feminina, aqui, é duplamente marginalizada; é considerada o "outro" em relação à metrópole, já que é nativa de uma colônia europeia, e é considerada o "outro" por ser mulher, ou seja, por fazer parte de um grupo sexual considerado marginal em relação ao grupo dominante.

"Coincidências" como essas acabaram por aproximar o discurso pós-colonial do feminista. Segundo Bonnici (2000, p.153), "a inter-relação e a interatividade entre os dois discursos são tão incisivas que o feminismo é considerado um tropo do segundo". Conceitos utilizados por teóricos pós-colonialistas para problematizar o relacionamento entre metrópole e colônia passam a ser utilizados por teóricas(os) feministas para investigar o discurso entre patriarcalismo e a condição da mulher - 
caso dos conceitos de linguagem, voz, discurso, silêncio, etc. Outro exemplo mencionado no estudo de Bonnici é o conceito de literatura canônica: como os pós-colonialistas, as(os) feministas também se deram conta de que o valor estético da literatura hegemônica não reside no próprio texto, não sendo, portanto, universal. Ao contrário, reside, muitas vezes, em fatores extratextuais, construídos histórica e culturalmente por ideologias dominantes, como a patriarcal.

Textos impregnados pela ideologia patriarcal acabam revelando, a contrapelo, nas brechas de seu discurso, a possibilidade de práticas de leitura diferenciadas por parte de correntes teóricas como a crítica feminista. Eles fornecem paradigmas que são desafiados pelo pensamento feminista, por meio de uma apropriação que se faz da forma utilizada para inferiorizar e submeter aquele que é visto como outro, como o diferente. Isso se dá através da escrita - o campo das representações. Assim, a reescrita, prática que redescobre, relê e reinventa o texto originário, apropria-se dele e o subverte. Seu objetivo é evidenciar as formas - como o patriarcalismo - por meio das quais se faz a dominação, formas estas operadas de maneira inconsciente ou não.

Mais uma contribuição do Pós-colonialismo ao Feminismo pode ser vislumbrada na postura de certas teóricas que passaram a reivindicar a incorporação da investigação de questões de raça e classe ao discurso feminista fundamentado nas relações de gênero, numa atitude de repúdio à repetição de clichês imperialistas, próprios do discurso colonialista. Gayatri Spivak, pensadora indiana radicada nos Estados Unidos, consiste num bom exemplo. Para ela, a Crítica Feminista não pode fazer desaparecer a heterogeneidade do Terceiro Mundo sob pena de tornar-se racista e colonialista.

Na seara da literatura brasileira de autoria feminina, e dos estudos críticos que se ocupam dela, muitas destas estratégias comuns aos discursos pós-coloniais e feministas têm se tornado cada vez mais recorrentes. A estratégia 
da reescrita tem sido, não raramente, utilizada pelas escritoras brasileiras numa atitude de reinvenção que põe em relevo o modo de construção e representação do universo da mulher. É o caso, por exemplo, de $A$ força do destino (1978), da escritora carioca Nélida Piñon, que reinventa a ópera do mesmo nome do italiano Giuseppe Verdi, em que a figura feminina central, construída no texto original como frágil, vulnerável e vítima, é reconstruída como uma mulher-sujeito, libertária, audaciosa, astuta e sedutora. Este, também, é o caso do romance de Ana Maria Machado, A audácia dessa mulher, publicado em 1999, que consiste no objeto de nossa investigação nesse trabalho. Trata-se de um texto que, em meio à teia narrativa que se desenvolve em torno da trajetória da audaciosa Beatriz Bueno, uma jornalista de sucesso ambientada no finalzinho do século $\mathrm{XX}$, reescreve e/ou reinventa a trajetória de Capitu, a protagonista de Dom Casmurro, de Machado de Assis.

Desafiar textos da tradição não é exclusividade do pensamento crítico feminista, mas tem sido uma prática adotada pelos grupos considerados minoritários em questões de poder. Essa atitude de desafio não deixa de levar em conta a poderosa capacidade absorvente do discurso dominante em suas mais diversas facetas, e não se contenta simplesmente com o "desmanche" dessa construção, mas procura, ao fazê-lo, expor e implodir os processos coercivos subjacentes aos textos, mostrando como operam com controles naturalizados e puramente convencionados, ideológicos.

Enquanto as leituras mais ingênuas do clássico romance oitocentista giram em torno da polêmica da culpa ou da inocência de Capitu, uma das personagens femininas mais discutidas da Literatura Brasileira, as leituras mais lúcidas enfatizam a questão do ciúme de Bentinho e a consequente impossibilidade de o leitor ter certeza se ele foi ou não traído pela mulher com seu melhor amigo. Isso porque o romance é narrado em primeira pessoa pelo próprio Bentinho, enlouquecido de ciúme, quando ele já 
se encontrava na velhice, visceralmente mergulhado na solidão e na sua casmurrice.

De qualquer modo, as críticas mais comuns, empreendidas pelos estudos contemporâneos de gênero, ao autor do romance se concentram no fato de ele ter construído uma figura feminina silenciada, sem vez e voz, bem aos moldes da ideologia patriarcal, que defendia a subjugação e o emudecimento da mulher. A Capitu acusada de adultério pelo marido, por meio de um discurso jurídico e, como tal, manipulador, é exilada com o filho na Suíça, onde morre na solidão e no abandono, sem direito à defesa. Daí a pergunta mais recorrente: quais seriam os contornos de Capitu senão aqueles que lhe conferem a ótica do marido-advogado?

Ana Maria Machado, em $A$ audácia dessa mulher, imbuída da crença de que "os livros continuam uns aos outros, apesar de nosso hábito de julgá-los separadamente" (MACHADO, 1999, p. 185), retoma a trajetória de Capitu, recriando-lhe os contornos, reinventando-lhe os caminhos percorridos durante o casamento com Bentinho e após seu exílio na Suíça.

Na verdade, não se trata de reescrever o romance nos mesmos moldes das reescritas anteriormente referidas. O texto de Ana Maria Machado se desenvolve fundamentalmente em torno da protagonista Beatriz; Capitu entra na história como um elemento a mais na construção de um universo feminino que se caracteriza pela capacidade de engendrar novas formas de estar na sociedade, apesar das adversidades advindas de ideologias milenares que se sustentam no aprisionamento da mulher no silêncio e na imobilidade.

E desse pensamento que se nutre o argumento central da retomada dessa história: o "cadernão da Lina", um misto de caderno de receitas e de diário íntimo que, após ter passado por diversas gerações de mulheres, durante mais de um século, chega às mãos de Beatriz, acompanhado de uma carta assinada por Maria Capitolina. A estratégia do livro consiste, portanto, em fazer com 
que Capitu, a personagem de ficção machadiana do século XIX, seja reconhecida por Beatriz, personagem de ficção ambientada no final do século XX, como uma mulher real que, apesar de ter sido também personagem de Machado, existiu de fato. Os fragmentos a seguir flagram o momento em que Beatriz tenta assimilar a situação:

\section{— Capitu?! Meu Deus!}

[...]

— Lina é Capitu? Não acredito! Não é possível!

[...]

Mas como é que eu podia desconfiar? Ela não existe... É só um personagem inventado... Todos eles são inventados, pura ficção.

Fiç̧ão ou não estava em suas mãos a carta. Contava tanta coisa que Bia já sabia, que lera e relera ao longo da vida mas esquecera ou bloqueara, e nem conseguira ligar aos fatos que fora reencontrando desde outro ponto de vista, narrados no caderno de receitas de Lina. Agora, acabara de ler as páginas que o acompanhavam. Carta assinada por Maria Capitolina. [...] agora ficara evidente que era Bentinho aquele namoradinho B., mencionado nas anotações da menina. O Bentinho seminarista com quem a jovem Capitu acabara se casando. O homem que, no fim da vida, chamando a si mesmo de Dom Casmurro, brilhantemente a condenara aos olhos do leitor pela pena de Machado de Assis.

Pois não podia ser verdade.

Mas era. (MACHADO, 1999, p. 196-7, grifos nossos)

Desse modo, está construída uma situação narrativa que permite a Ana Maria Machado, no limiar do século XXI, de posse de todas as conquistas viabilizadas pelo feminismo em relação ao modo de estar da mulher na sociedade, engendrar uma narrativa que funciona como resposta feminista à ideologia patriarcal que subjaz à construção de Dom Casmurro. Não se trata, 
absolutamente, de minimizar a importância desse clássico romance oitocentista. Trata-se, antes, de pôr em prática - pensamento de Virgínia Woolf de que os livros continuam uns aos outros, referido pela própria autora no capítulo 16 em que assume o discurso para lembrar aos seus leitores, sobretudo àqueles chamados por Stendhal de "happy few", que não sentem "horror a delicadezas ou outros lavores sutis", que é por eles que ela escreve, por ela mesma, numa atitude de quem aprecia os ecos que emanam do "contínuo fluxo de livros que se esparramam por nossa vida e a fecundam" (MACHADO, 1999, p. 186-7).

Nesse sentido, a reescrita pode ser comparada com a escrita que se fazia num pergaminho, denominado palimpsesto, no qual eram feitas inscrições que se sobrepunham à escrita anterior. $\mathrm{O}$ ato de escrever "por cima" acarreta a substituição de uma forma de pensar. No entanto, a presença de rastros que não se apagam sugere que as inscrições anteriores permanecem como uma característica ininterrupta do "texto" da cultura. A experiência cultural é, ela mesma, um acúmulo de muitas camadas, e cada período histórico, com suas mudanças de comportamento e ponto de vista particular, reescreve o anterior, apagando-o. Porém, os rastros permanecem inscritos na cultura. Portanto, o momento atual se constitui do acúmulo de saberes anteriores, que vão sendo reavaliados, transformados, remodelados e re-significados.

Dessa forma, podemos entender a literatura e toda a cultura como algo híbrido, emaranhado, entrelaçado, com elementos costumeiramente vistos como estranhos. Reencontrar tais vestígios do passado e sua assimilação no presente é imprescindivel para entender o funcionamento da literatura e de sua função representativa. Isso porque os textos formam uma continuidade. A cultura nos legou uma formação discursiva que não podemos exterminar completamente, mas que podemos re-fazer, reinventar por meio de outras bases, procurando desautorizar os paradigmas anteriores. 
Portanto, é possível subjugar o texto canônico, mas justamente por cima dele, sem negar sua existência efetivamente histórica e suas influências empíricas e no campo ideológico, ainda que tais influências estejam sendo, por meio da reescrita, assimiladas, transformadas e reelaboradas.

Isso nos remete a uma corrente formada pelas composições textuais, ou a um quebra-cabeças, no qual cada elo liga-se ao anterior e ao mesmo tempo fornece base para o encaixe do posterior. Desse modo, toda literatura é intertextual. Assim, um texto específico não é delimitado claramente - ele se espalha pelas obras que estão à sua volta.

É dentro desse espírito e/ou desejo de dar prosseguimento às narrativas de outros tempos, as quais de um jeito, ou de outro, refletem a sociedade da época, que os caminhos que teriam sido trilhados por Capitu, e que não caberiam no campo de visão do narrador Dom Casmurro, são iluminados em $A$ audácia dessa mulher. Tudo o que não foi dado ao leitor do romance original saber sobre essa intrigante personagem feminina, a quem Machado não deu voz, sendo-lhe o perfil filtrado pela ótica do marido ciumento, é permitido conhecer agora.

A carta destinada a Sancha, que acompanha o caderno de receitas, enviada quarenta anos após Capitu ter sido exilada na Suíça, tem a missão de trazer a ambas um pouco de paz. É que apesar de Capitu ter presenciado, na véspera da morte de Escobar, uma intensa troca de olhares entre o marido e a melhor amiga, ela não lhe guardou ressentimentos. Essa revelação, que inverte a situação básica do romance oitocentista, já que Capitu passa de adúltera para vítima de traição, desencadeia uma série de outras situações que funcionam como respostas às lacunas deixadas no texto original em relação ao comportamento da protagonista.

Essa inversão é possível porque, de acordo com Ashcroft (2001), ao se expor, o sistema hegemônico abre brechas para a atuação do outro, pois o discurso 
dominante tem as fragilidades de qualquer outro: "no discourse is seamless and totalitarian, no discourse is immune to doubt and reflexivity, and the fractures which open up within it allow for forms of resistance which operate within discourse, on many of its own terms". ["Nenhum discurso é sem costura e totalizador, nenhum discurso é imune à dúvida e reflexão, e as fraturas que se abrem no seu interior permitem surgir formas de resistência as quais operam dentro dele, em alguns de seus próprios termos"] (ASHCROFT, 2001, p. 32 e 33 - tradução nossa).

Portanto, a reescrita ou contra-discurso canônico opera dentro do discurso da própria literatura. Textos literários canônicos são tão "consumidos" que, de certo modo, tornam-se a base da resistência, no sentido de que estão fornecendo matéria e sendo tomados como pontos de partida para releituras e refacções, isto é, para a prática de escritas re-inventadas - ou inventadas à revelia que visam alterar significativamente o funcionamento de tais paradigmas.

Textos são apropriados e a partir deles são produzidas novas versões, as quais subvertem subitamente os valores e pressupostos políticos dos originais. $\mathrm{O}$ significado dos textos que são relidos revela que eles oferecem poderosas alegorias da cultura dominante, alegorias através das quais a vida nas sociedades tem "reescrito" a si mesma, revelando facetas até então desconhecidas, ignoradas, ou mesmo sufocadas.

Essa prática e teoria que norteia a refaccão do texto "canônico" passa pela contra-leitura subversiva, uma resistência no campo simbólico. Ela produz um contradiscurso que, ao subverter o discurso canônico, o reinterpreta, gerando sua reescrita. A reescrita, em atuação na literatura de autoria femininina, pode ser definida como uma prática discursiva que se aproveita de lacunas, silêncios, alegorias, ironias e metáforas do texto "canônico" para subverter suas bases, pressupostos e valores. É a construção de um novo texto, que interroga o primeiro, 
através de questionamentos s subversões, rebates a preconceitos, revides femininos e outros mecanismos subversivos (BONNICI, 2005).

Um exemplo de apropriação das brechas no discurso canônico e reconstrução de seu sentido é a versão de Capitu do desespero que demonstrou diante do cadáver de Escobar, desespero este que funcionou, aos olhos de Bentinho, como uma confissão de culpa da relação adúltera que teria com o melhor amigo dele:

[...] soube que Santiago fora chamado às pressas à tua casa, porque teu marido se afogara. Não pude deixar de recordar, imediatamente, que ainda na véspera eu pensara em sua morte, e na minha também. Igualmente pensara em tua morte e na de meu marido, cheguei a pedir aos céus que elas se abatessem, tão ferida e dilacerada me encontrava eu com a descoberta da traição. [...] Ao olhar fixamente o cadáver, supliquei com todas as minhas forças que ele me levasse consigo, pensei em lançarme no mesmo mar que o levara e que agora me atraía, como se a única maneira de findar meu sofrimento fosse ser tragada pela mesma ressaca que o arrebatara e que ainda bramia diante da casa. (MACHADO, 1999, p. 189-90)

Essa revelação contém uma inversão de papéis. Nessa nova versão, traçada por Ana Maria Machado, Capitu era quem possuía motivos concretos para acreditar que era traída. Dessa forma, aqueles que foram marginalizados encontram um jeito de driblar o controle imposto. O outro oprimido - no nosso caso, a mulher refaz a estrutura do texto canônico e subjuga suas prerrogativas por meio da reescrita, ou escrita subversiva, usurpando o poder da língua e, consequentemente, do discurso histórico, para desvelar uma versão diferente da mesma história. É uma tentativa de reescrever a ambos: história e literatura, através de uma resistência à versão 
oficial, esta carregada de pressupostos, estereótipos e preconceitos. Daí explica-se a existência e perenidade do diário de Capitu, simbolizando a contínua possibilidade de resistência por parte dos que foram relegados à periferia, possibilidade contida nas próprias fendas do discurso que se pretende hegemônico.

Dessa forma, entende-se a disputa pelo poder de narrar, reprimido pelo dominador quando o outro quer usálo para lançar mão de seus efeitos e veicular sua própria versão da história, na tentativa de opor-lhe resistência. Assim, o silenciamento da mulher em épocas e de maneiras diversas se deu em função do cerceamento de sua possibilidade de uso da linguagem, a qual tem servido, muitas vezes, como instrumento na constituição e manutenção do domínio da hegemonia pretendida pelo dominador. $O$ processo da reescrita, entretanto, opera na contramão desse propósito, pois estabelece uma oposição, uma voz no interior do próprio dogma do discurso dominante, através da revelação das contradições sobre as quais se fundamenta tal discurso.

No entanto, a reescrita não se resume na inserção de uma voz contestatória ou de uma perspectiva radical, embora possa conter tudo isso, mas de um mergulho a fundo no cerne do discurso dominante, que tem como resultado o rompimento de suas características discursivas e a revelação das limitações desse mesmo discurso, o que se dá por meios da desconstrução das bases de pressupostos e pré-conceitos da qual se nutre. $\mathrm{O}$ texto subversivo é, antes de tudo, contra-discursivo. Ele não se limita a inverter o jogo entre dominador e dominado, em deslocar os papéis de 'Outro' e 'outro'. Seu objetivo é desmistificar o próprio jogo, o que concorre para a criação de locais de resistência; isto é, rupturas na representação do discurso dominante.

Essa visão transformadora deve vir de um outro lugar, diferente daquele ocupado pelo discurso homogêneo, ou seja, precisa surgir dos pontos cegos não focalizados, do espaço não representado, mas 
implícito - não visto - nesses discursos; das brechas dos aparelhos de poder-conhecimento, conforme esclarece Lauretis (1994); além de ser acompanhada, conforme ressalta Tiffin (1995), por uma integridade nova ou realidade totalmente recuperada. Esta deve ser livre de toda tentativa de dominação, tendo em vista a experiência que expôs a natureza do relacionamento anterior entre os gêneros, extremamente desigual. Nesse intento se revela a força da nova representação da mulher veiculada pela reescrita de Dom Casmurro empreendida por Ana Maria Machado. A atitude ideológica da autora parece ser pautada por esses propósitos, isto é: atuar nos vazios e brechas do texto canônico e, simultaneamente, criar uma realidade nova, livre das regras de oposição presentes no jogo sujeito/ objeto. Ela o faz de diferentes formas, seja pela desmistificação da oposição dominador/dominador, promovida especialmente por meio da personagem Bia, que se nega a enxergar, aceitar e vivenciar a relação entre os sexos nesses termos, seja pela valorização do hibridismo da constituição da identidade de Capitu, o qual promove a inversão dos valores construídos pelo discurso homogeneizador.

Dessa forma, A audácia dessa mulher pode ser um texto entendido como um concerto de muitas vozes ideológicas, em conflito e diálogo umas com as outras. Para chegar a uma leitura que inclua o reconhecimento da polifonia de vozes existentes no romance de Ana Maria Machado, é importante verificar não só o que se narra, mas comose narra, pois "é a linguagem que fala na literatura, em toda a sua complexa pluralidade "polissêmica', e não o autor" (EAGLETON, 2001, p. 190). Note-se o que argumenta Said a respeito da necessidade de uma leitura em contraponto para a compreensão não só da maneira como atua o pensamento dominante, bem como para potencializar o entendimento do funcionamento conjunto dos textos: 
Quando voltamos ao arquivo cultural, começamos a relê-lo de forma não unívoca, mas em contraponto, com a consciência simultânea da história metropolitana que está sendo narrada e daquelas outras histórias contra (e junto com) as quais atua o discurso dominante. No contraponto da música clássica ocidental, vários temas se opõem uns aos outros; na polifonia resultante, porém, há ordem e concerto, uma interação organizada que deriva dos temas, e não de um princípio melódico ou formal rigoroso externo à obra. Da mesma forma, creio eu, podemos ler e interpretar os romances... (1995, p. 87).

Fatores como o encobrimento ou desnudamento de certas questões numa narrativa, o silenciamento de determinadas vozes, o emprego de estratégias que põem em relevo determinados personagens e ideologias, bem como as formas de narrar, ou seja, as escolhas feitas pelos autores e as condições que as motivaram são fundamentais para a análise crítica quando tomados ambos os lados da questão, isto é, o do dominador e o do dominado. Uma leitura em contraponto, mais abrangente, também leva em consideração as épocas referentes à atuação das personagens, os respectivos contextos e as relações entre ambos.

À surpreendente reviravolta na história de Dom Casmurro, a qual resulta no revide feminista contido no texto de Ana Maria Machado, soma-se uma série de outras informações que subvertem a imagem e o destino que são conferidos a Capitu em Dom Casmurro: 1) a decisão da separação é dela, e não do marido; 2) a semelhança entre Ezequiel e Escobar desaparece: "bastava ver como o rapaz era bem mais baixo, menos cheio de corpo, e como todas as suas cores eram diversas, vivas" (MACHADO, 1999, p. 194); 3) ela responde à situação disfórica com uma vida nova: ela tem a "audácia de se parir novamente" (MACHADO, 1999, p. 199). 
Nesse sentido, Ana Maria Machado reinventa a trajetória de Capitu a partir dos elementos fundamentais que conferiam a ela, no texto original, o status de "escrava branca" (COSTA LIMA, 1981, p. 90). Ao invés de ter sido, simplesmente, exilada na Suíça, sem maiores explicações, ela surpreende Bentinho tentando envenenar Ezequiel e acaba por obter dele a acusação formal de adultério. Daí preferir a separação a manter um casamento - que.se mostrava insustentável. A opção pela Suíça vem do fato de o marido, como no texto original, fazer questão de manter as aparências perante a sociedade. Do mesmo modo, o registro do desaparecimento da semelhança entre Ezequiel e Escobar, na reescrita da escritora contemporânea, aponta para a desconstrução de uma possibilidade que, apesar de bem plausivel, não foi, sequer, considerada pelo narrador do texto original. Por fim, é fundamental na reescrita de Ana Maria Machado, o fato de Capitu ser capaz de reinventar, a partir do nada, uma nova vida e dar sentido a ela. Apenas aparentemente ela cumpre a sina da mulher adúltera que, após ser desmascarada, morre na solidão e no abandono como forma de purgar seus pecados. $\mathrm{Na}$ verdade, ela ignora o rótulo que lhe foi conferido de "fêmea infiel" e constrói uma vida digna a partir de seus próprios méritos. $O$ fato de ter abandonado o apelido de menina e de ter passado a usar a outra metade de seu nome — Lina — , numa atitude de Fênix, aponta para a capacidade da mulher em engendrar sua própria história, apesar das adversidades impostas por ideologias como a patriarcal.

Contudo, a intertextualidade com os textos canônicos, promovida pela releitura e reescrita de determinada obra, é crucial, pois é dela que se nutre a resistência - das brechas existentes em sua ideologia contraditória (ASHCROFT, 1998), as quais podem ser invertidas e causar uma des-identificação dos sujeitos com os parâmetros que seguia sem questionar, provocando a ruína da homogeneizaçâo promovida pela força discursiva dominante. 
De acordo com o teórico Foucault (1979), nossa subjetividade é construída através do discurso, de maneira que identificamo-nos ou reagimos contra as posições de sujeito que nos são fornecidas em determinado momento. $\mathrm{E}$ justamente porque somos constituídos pela linguagem, a literatura é o local privilegiado para questionamentos, articulação e construção de identidades. Podemos visualizar a formação de uma identidade no texto canônico quando o narrador de Dom Casmurro, Bentinho, exibe uma postura de sujeito que se quer estável, procurando atribuir significados a seu mundo, tirando do que considera como sua realidade um sentido para suas vivências, mesmo que através da imposição do silenciamento do outro (a mulher, Capitu), impossibilitado de ser realmente ouvido. Sua identidade, calcada na tradição burguesa e no modo desta de apreender o mundo, faz com que ele se volte em busca de uma resposta quanto à possibilidade de ter sido traído: somente a "verdade", os "fatos" o interessam. O que ele não percebe ou prefere omitir é que, com base no seu próprio julgamento, ele mesmo dará uma sentença ao caso. Isto é, com base nos pressupostos da classe dominante com a qual se identifica.

Já em $A$ audácia dessa mulher, verificamos o sujeito (seja Bia ou a Capitu de Ana Maria Machado) como um espaço onde se articulam o individual e o coletivo, o privado e o público. Ou seja, a obra lida com um sujeito articulado em termos de sua alteridade, que reconhece não ser capaz de aglutinar todas as "verdades", pois entende que a realidade é constituída por uma multiplicidade e diversidade de escolhas e possibilidades que é benéfica. Isso acaba por desestabilizar os significados sedimentados do discurso patriarcal, pois ele se erige sobre verdades prontas e acabadas, e busca não deixar espaço para dúvidas. Entretanto, isso o torna ainda mais questionável, pois nenhum discurso é imune a questionamentos, visto que é erigido sobre linguagem e, consequentemente, pode ser também por ela interpelado. Dessa maneira, nota-se que a subversão discursiva promovida pela reescrita se 
dá por meio do enviesamento de conceitos culturais sedimenzados, como fósseis no inconsciente coletivo.

A fragmentação da identidade, ou seja, a constituição do que se pode chamar de sujeito híbrido, multifacetado, não é explorada no primeiro romance, pois o momento de ênfase no cientificismo reclama uma busca por verdades estáveis, uma organização do mundo que dê segurança ao sujeito de conhecer os fatos e a própria realidade. Tem-se a pretensão de que há uma verdade a ser explorada, e o autor seria aquele ser capaz de conduzirnos a ela.

Já no segundo romance, a fragmentação é a própria mola-mestra que permite flexibilidade e capacidade de adaptação ao sujeito. É enfocada sua natureza criativa, como o surgimento de uma nova identidade: Capitu, ao reconstruir sua vida, deixa seu apelido de menina e assume a outra metade de seu nome, Lina. Ela é capaz de refazerse. Sua identidade, híbrida, teve que se adaptar às diferentes condições pelas quais passou - de menina pobre à esposa abastada, e depois à mulher independente, na obra da autora. Já Bentinho, acostumado a uma identidade fixa, inflexível, não consegue se colocar em diferentes ângulos.

O hibridismo, portanto, é apresentado de forma positiva. Dá-se uma inversão de valores através da reescrita promovida por Ana Maria Machado, tendo em vista que o discurso dominante promove a homogeneização. O processo de re-visão tem por objetivo não apenas apontar lacunas, brechas ou incorreções, mas, em meio a isso, recriar em termos afirmativos o surgimento de algo novo, com implicações e valores diferentes, permitindo ao sujeito, anteriormente tomado como fixo, estável, ver as alteridades que o constituem, um equilíbrio de forças, vozes e culturas eclipsadas que normalmente se é forçado a ignorar. Esses elementos "estranhos" colaboram para a formação do sujeito, ou seja, refletem a presença da alteridade na identidade. A eliminação da alteridade, por outro lado, causaria uma leitura unilateral 
do mundo, isto é, uma dificuldade e recusa em lê-lo de qualquer outro modo. Tal como sua personagem, Ana Maria Machado revela sua posição ideológica na própria forma como constrói sua reescrita, ou seja, lançando mão do hibridismo ao "misturar" elementos aparentemente contraditórios, como a resistência e o revide à dominação (a inversão de papéis entre sujeito e objeto) e a possibilidade de criação de uma nova forma de encarar e viver a relação entre os sexos, fora dos parâmetros de dominação instituídos pelo discurso dominante, que tenha a liberdade para instituir suas próprias regras.

Além disso ganha relevo, nesta nova trajetória que Ana Maria Machado confere a Capitu, em que o elemento "parir-se novamente" é central e decisivo, o fato de este ato ser sustentado por dois pilares fundamentais: a conquista da vida profissional e o desejo de mulher de redefinir os papéis sociais que representa. No que diz respeito ao primeiro, a vida profissional que vai aos poucos conquistando lhe viabiliza a independência definitiva: ela passa de ajudante de cozinha, em uma pensão, para camareira, depois para governanta e, finalmente, para proprietária. Isso lhe garante o direito de cortar os laços que a ligam ao marido opressor e à "escravidão branca" que encontrava na mulher do tempo seu objeto. Em relação ao segundo pilar referido, não se pode deixar de considerar que, embora a reescrita da trajetória da personagem machadiana lhe preserve a ambientação no século XIX, ela se concretiza dentro de um outro contexto. Trata-se de uma homenagem a Machado de Assis, no ano do centenário da publicação de Dom Casmurro, realizada em um momento em que é visível na literatura, sobretudo na literatura de autoria feminina, a representação da nova situação da mulher na sociedade, viabilizada pelo movimento feminista.

O texto de Ana Maria Machado, portanto, ecoando as tendências emanadas das discussões incentivadas pelo "multiculturalismo", pensamento implementado nesse final de século XX, que tem 
incentivado a emergência do diferente, das vozes divergentes e marginalizadas, salientado os conceitos de "Alteridade" e de "O Outro", traz à tona a discussão da necessária redefinição dos papéis sociais da mulher, os quais apontam não para a igualdade em relação ao sexo oposto, mas para o fato de as mulheres assumirem a autoria da própria vida, de seu destino, do feminino, enfim. 


\section{Referências}

AHMAD, A. Linhagens do presente. São Paulo: Boitempo, 2002.

ASHCROFT, B. Post-colonial transformation. Londres:

Routledge, 2001.

BONNICI, T. O pós-colonialismo e a literatura. Maringá:

Eduem, 2000.

BRONTË, C. Jane Eyre. Harmondsworth: Penguin, 1956

COETZE. Foe. Harmondsworth: Penguin, 1987.

COSTA LIMA, L. Dispersa demanda. Rio de Janeiro: Francisco Alves, 1981.

DEFOE, D. Robinson Crusoé Lisboa: Publicações EuropaAmérica, s/d.

DERRIDA, J. A escritura e a diferença. Tradução: Maria Beatriz Marques Nizza da Silva. 3. ed. São Paulo: Perspectiva, 2002.

FOUCAULT, M. A história da sexualidade: a vontade de saber. Vol. 1. Rio de Janeiro: Graal, 1979.

LAURETIS, T. A tecnologia do gênero. In: HOLLANDA, H. B. (Org.). Tendências e impasses o feminismo como crítica da cultura. Rio de Janeiro: Rocco, 1994, p. 206-242.

MACHADO, A. M. A audácia dessa mulher. Rio de Janeiro: Nova Fronteira, 1999.

MACHADO DE ASSIS, J. M. Dom Casmurro. São Paulo: Egéria, 1978.

PIÑON, N. A força do destino. Rio de Janeiro: Record, 1997. 
RHYS. J. Wide sargasso sea. Harmondsworth: Penguin, 1968.

TIFFIN, H. Post-colonial literatures and counter discourse. In: ASHCROFT, B.; GRIFFITHS, G.; TIFFIN, H. (Org.). The postcolonial studies reader. Londres: Routledge, 1995, p. 95-103. 